\title{
RAGAM TINDAK TUTUR MEMINTA MAAF DAN KAITANNYA DENGAN PEMBELAJARAN BIPA TINGKAT A1
}

\author{
Atik Widyaningrum \\ Universitas Ahmad Dahlan \\ atik1915003106@webmail.uad.ac.id
}

\begin{abstract}
Abstrak
Tindak tutur yaitu sebuah tindakan dalam bentuk tuturan. Tindak tutur meminta maaf merupakan sebuah tindakan dalam bentuk tuturan meminta maaf. Penelitian ini bertujuan untuk mempelajari dan memahami pentingnya tindak tutur meminta maaf serta mengajarkan kepada pemelajar bahasa Indonesia bagi penutur asing (BIPA), terutama tingkat atau jenjang Al (prapemula) dalam mengimplementasikan ragam tindak tutur meminta maaf sesuai dengan fungsi dan peranannya dalam percakapan sehari-hari. Sehingga, pemelajar BIPA dapat menggunakan dan menerapkan tindak tutur meminta maaf yang baik dan benar ketika berbicara dalam bahasa Indonesia. Tindak tutur meminta maaf berkaitan dengan kesantunan berbahasa. Penelitian ini menggunakan metode kualitatif yang bersifat deskriptif yaitu suatu proses analisis data yang dilakukan melalui tahap studi pustaka. Hasil penelitian menunjukkan bahwa, terdapat dua bentuk tindak tutur meminta maaf, yaitu maaf dan ampun. Tindak tutur maaf dibagi menjadi lima ragam, sedangkan tindak tutur ampun dibagi menjadi dua ragam.
\end{abstract}

Kata kunci: tindak tutur meminta maaf, kesantunan berbahasa, BIPA

\section{PENDAHULUAN}

Tindak tutur memiliki peranan penting dalam aktivitas berbahasa. Menurut Fitriah \& Fitriani (2017: 52) tindak tutur merupakan suatu kegiatan berbahasa yang dilakukan oleh penutur untuk mengomunikasikan makna serta maksud tuturan kepada lawan tutur. Tindak tutur dapat diklasifikasikan menjadi tiga, yaitu tindak tutur lokusi (locutionary acts), tindak tutur ilokusi (illocutionary acts), dan tindak tutur perlokusi (perlocutionary acts). Tuturan ekspresif merupakan bagian dari tindak tutur ilokusi. Tuturan ekspresif adalah tindak tutur yang dimaksudkan penuturnya agar ujaran tersebut dapat diartikan sebagai evaluasi tentang hal yang disebutkan dalam tuturan itu dan memiliki beberapa fungsi di dalamnya. Tuturan ekspresif memiliki beberapa fungsi yang terdiri dari mengkritik/menyindir, mengeluh, menyalahkan, mengucapkan selamat, mengucapkan terima kasih, menyanjung, dan meminta maaf (Sari, 2012: 2). Salah satu peristiwa tutur yang menuntut adanya kemampuan yang baik dalam bertutur adalah tatkala meminta maaf (Ridwan, 1996: 126).

Tindak tutur meminta maaf merupakan suatu kegiatan berbahasa yang dilakukan penutur dengan maksud menyampaikan permintaan maaf kepada lawan tutur. Tindak tutur meminta maaf terbagi menjadi dua bentuk, yaitu tindak tutur maaf dan ampun. Masing-masing tindak tutur maaf maupun ampun memiliki ragam tersendiri. Tindak tutur maaf diklasifikasikan menjadi lima ragam tindak tutur. Sedangkan tindak tutur ampun diklasifikasikan menjadi dua ragam tindak tutur. Ragam tindak tutur maaf dan ampun tersebut memiliki fungsi dan peranannya masing-masing dalam percakapan bahasa Indonesia. Beragamnya bentuk tindak tutur meminta maaf menjadikan hal tersebut penting untuk dikaji, karena masih banyak penutur yang belum memahami fungsi dan peran dari masing-masing ragam tindak tutur meminta maaf yang ada. Hal itu berpengaruh terhadap tingkat kesantunan berbahasa seseorang, karena bahasa Indonesia yang baik dan benar yaitu penggunaan bahasa yang tepat sesuai dengan fungsi dan peranannya.

Santun berbahasa merupakan sikap hormat penutur kepada lawan tutur yang diwujudkan melalui tuturan. Kesantunan adalah salah satu cerminan terpenting dari diri manusia karena manusia tidak dapat 
hidup satu sama lain dan berkomunikasi. Masing-masing budaya dan bahasa memiliki cara untuk menunjukkan rasa hormat dan penghormatan, menutupi kesalahan, menghindari dan atau meminimalkan pemaksaan. Jadi, kesantunan berbahasa merupakan seperangkat prinsip yang disepakati oleh masyarakat bahasa untuk menciptakan hubungan saling menghargai antara anggota masyarakat pemakai bahasa yang satu dengan yang lain (Ridwan, 1996: 126). Oleh karena itu, ragam tindak tutur meminta maaf tidak hanya penting untuk diajarkan kepada penutur Bahasa Indonesia saja, tetapi juga penting untuk diajarkan kepada pemelajar BIPA terutama tingkat atau jenjang A1 (prapemula). Hal tersebut mengingat begitu banyaknya ragam tindak tutur meminta maaf, sehingga para pemelajar BIPA merasa kesulitan untuk membedakan ragam mana yang akan mereka gunakan ketika berbicara dalam situasi tertentu.

Berkaitan dengan ragam tindak tutur meminta maaf, penelitian yang relevan dan lebih dahulu dilakukan pertama oleh Muhammad Ridwan. 1996. Universitas Sebelas Maret. Penelitian tersebut berjudul "Kajian Sosiopragmatik Tuturan Permohonan Maaf Oleh Penutur Bahasa Arab Di Mesir". Persamaan penelitian Muhammad Ridwan dengan penelitian ini terletak pada objek penelitian, yaitu tentang tindak tutur meminta maaf. Namun, dalam penelitian Muhammad Ridwan berkaitan dengan penutur bahasa Arab di Mesir, sedangkan dalam penelitian ini berkaitan dengan pembelajaran bahasa Indonesia Bagi Penutur Asing (BIPA). Kedua, penelitian yang relevan dan lebih dahulu dilakukan oleh Diana Kartika. 2017. Universitas Bung Hatta. Penelitian tersebut berjudul "Strategi dan Modifikasi Kesantunan Tindak Tutur Memohon Oleh Mahasiswa Jepang Pada Program Bahasa Indonesia Bagi Penutur Asing (BIPA)”. Persamaan penelitian Diana Kartika dengan penelitian ini terletak pada objek penelitian, yaitu tentang tindak tutur kaitannya dengan pembelajaran BIPA. Keduanya membahas mengenai tindak tutur yang menunjukkan kesantunan dalam berbahasa. Namun, dalam penelitian Diana Kartika tindak tutur yang diteliti yaitu mengenai tindak tutur memohon, sedangkan dalam penelitian ini tindak tutur yang diteliti adalah tindak tutur meminta maaf. Ketiga, penelitian yang relevan dan lebih dahulu dilakukan oleh Maslida Yusof, dkk. 2011. Penelitian tersebut berjudul “Ooops.. Maaf: Strategi Kesopanan dan Penebus Kesalahan”. Persaman penelitian Maslida Yusof, dkk. dengan penelitian ini terletak pada objek penelitian, yaitu tentang tindak tutur meminta maaf sebagai bentuk kesantunan berbahasa. Keduanya membahas mengenai bentuk, ragam, dan contoh tuturan maaf. Namun, dalam penelitian Maslida Yusof, dkk. subjeknya adalah pelajar Universiti Kebangsaan Malaysia, sedangkan dalam penelitian ini subjeknya adalah semua penutur bahasa Indonesia dan pemelajar BIPA terutama tingkat A1.

Berdasarkan uraian di atas, penelitian ini bertujuan untuk mempelajari dan memahami pentingnya tindak tutur meminta maaf serta mengajarkan kepada pemelajar bahasa Indonesia bagi penutur asing (BIPA), terutama tingkat atau jenjang A1 (prapemula) dalam mengimplementasikan ragam tindak tutur meminta maaf sesuai dengan fungsi dan peranannya dalam percakapan sehari-hari. Menurut Kartika (2017: 137) dalam mengajarkan bahasa Indonesia kepada penutur asing, pengajar perlu membekali pemelajar dengan kesantunan berbahasa dalam bertutur di samping bekal pengetahuan tata bahasa. Dengan mempelajari dan memahami ragam tidak tutur meminta maaf sesuai dengan fungsi dan peranannya, harapannya pemelajar BIPA dapat berbicara secara santun kepada mitra tutur sesuai dengan situasi tertentu. 


\section{LANDASAN TEORI}

Sebagaimana yang telah dikemukakan sebelumnya bahwa tindak tutur adalah suatu kegiatan berbahasa yang dilakukan oleh penutur untuk mengomunikasikan makna serta maksud tuturan kepada lawan tutur (Fitriah \& Fitriani, 2017: 52). Richard (1995) mengemukakan bahwa tindak tutur adalah istilah minimal dari pemakaian situasi tutur/ peristiwa tutur/ tindak tutur. Ketika kita berbicara, kita melakukan tindakantindakan seperti memberi laporan, membuat pernyataan-pernyataan, mengajukan pertanyaan, memberi peringatan, memberi janji, menyetujui, menyesal dan meminta maaf. Berkenaan dengan tindak tutur ini Chaer dan Leonie Agustine (1995) berpendapat bahwa tindak tutur merupakan gejala individual, bersifat psikologis, dan keberlangsungannya ditentukan oleh kemampuan bahasa si penutur dalam menghadapi situasi tertentu. Dalam tindak tutur itu yang lebih dilihat adalah makna atau arti tindakan dalam tuturannya (Purba, 2011: 79). Tindak tutur merupakan pandangan yang menegaskan bahwa sebuah ungkapan suatu bahasa yang dapat dipahami dan dimengerti dengan baik, apabila dikaitkan dengan situasi konteks terjadinya ungkapan tersebut yang kemudian memunculkan sebuah makna (Sari, 2012: 3).

Menurut John R. Searle (1969) dalam praktik penggunaan bahasa di masyarakat, terdapat setidaknya tiga macam tindak tutur yang harus dipahami bersama, di antaranya tindak tutur lokusi (locutionary acts), tindak tutur ilokusi (illocutionary acts), dan tindak tutur perlokusi (perlocutionary acts). Tindak tutur lokusi adalah tindak tutur untuk menyatakan sesuatu. Tindak tutur lokusi merupakan suatu tindakan bertutur yang dapat berupa kata, frasa, ataupun kalimat sesuai dengan makna yang terkandung dalam kata, frasa, ataupun kalimat itu sendiri. Tindak tutur ilokusi adalah tindak tutur yang selain berfungsi untuk mengatakan sesuatu dan dapat juga dipergunakan untuk melakukan sesuatu. Tindak tutur ini merupakan tindak tutur yang maksud penyampaiannya bergantung pada siapa, kapan, dan di mana tuturan tersebut dilakukan, sehingga tuturan ini tidak mudah diidentifikasi begitu saja seperti tindak tutur lokusi. Menurut Searle (1969) tindak tutur ilokusi digolongkan ke dalam lima macam bentuk tuturan yang masing-masing memiliki fungsi komunikatifnya sendiri-sendiri. Kelima macam bentuk tuturan tersebut adalah asertif, direktif, deklarasi, komisif, dan ekspresif. Tindak tutur perlokusi adalah tindak tutur yang diutarakan oleh seseorang dan seringkali mempunyai daya pengaruh (perlocution force) atau efek bagi yang mendengarkannya (Sari, 2012: 3).

Seperti yang telah dijelaskan sebelumnya bahwa tuturan ekspresif merupakan bagian dari tindak tutur ilokusi. Menurut Searle (1969), tuturan ekspresif adalah bentuk tuturan yang dimaksudkan untuk menyatakan atau menunjukkan sikap psikologis penutur terhadap suatu keadaan. Tuturan ini diutarakan dengan maksud agar ujaran yang disampaikan oleh penutur kepada lawan tuturnya dapat diartikan sebagai evaluasi mengenai hal yang disebutkan di dalam ujaran itu. Adapun beberapa fungsi tuturan ekspresif yang terkandung dalam sebuah ujaran yang disampaikan oleh penutur kepada lawan tuturnya, yakni dapat berfungsi untuk mengucapkan selamat, terima kasih, mengkritik, mengeluh, menyalahkan, memuji, menyindir, dan meminta maaf (Sari, 2012: 3).

Tindak tutur meminta maaf merupakan suatu kegiatan berbahasa yang dilakukan penutur dengan maksud menyampaikan permintaan maaf kepada lawan tutur. Salah satu peristiwa tutur yang menuntut adanya kemampuan yang baik dalam bertutur adalah tatkala meminta maaf. Permintaan maaf didefinisikan sebagai suatu tindak tutur yang ditujukan untuk memberikan dukungan pada mitra tutur yang sebenarnya 
atau berpotensi telah melakukan pelanggaran Olshtain (Ridwan, 1996: 126). Meminta maaf merupakan suatu tuturan yang di dalamnya terkandung tindakan agar mitra tutur berbuat sesuai dengan maksud tuturan Revita (Ridwan, 1996: 126-127). Dengan kata lain, maksud permintaan itu menjadi dasar mitra tutur dalam bertindak. Pada umumnya, permintaan maaf termasuk dalam tindak tutur ekspresif yaitu penutur mencoba untuk menunjukkan sikapnya sendiri. Bentuk tindak tutur maaf dan ampun memiliki beberapa ragam yang biasa digunakan dalam percakapan sehari-hari antara lain, maaf, minta maaf, mohon maaf, ampun, minta ampun, mohon ampun, maafkan, dan sori.

Semua orang perlu mempelajari dan memahami ragam tindak tutur meminta maaf, karena pemahaman terhadap tindak tutur meminta maaf akan sangat berpengaruh terhadap kesantunan seorang penutur dalam bertutur. Masih banyak penutur yang sering salah dalam memilih ragam tindak tutur meminta maaf ketika ia berbicara dengan mitra tutur, karena begitu banyaknya ragam tindak tutur meminta maaf yang ada dan mereka belum memahami fungsi serta penggunaan dari masing-masing ragam tindak tutur meminta maaf tersebut. Kesalahan itu sering dilakukan oleh penutur terutama oleh seorang pemelajar BIPA. BIPA adalah program pembelajaran keterampilan berbahasa Indonesia, meliputi berbicara, menulis, membaca, dan mendengarkan bagi penutur asing. Sedangkan pembelajar BIPA adalah mahasiswa asing yang mempelajari bahasa Indonesia.

\section{HASIL PENELITIAN DAN PEMBAHASAN}

Penulis menemukan dua bentuk tindak tutur meminta maaf yang masing-masing memiliki fungsi dan peranan tersendiri dalam percakapan bahasa Indonesia. Dua bentuk tindak tutur meminta maaf tersebut adalah maaf dan ampun. Tidak tutur maaf dibagi menjadi lima ragam tindak tutur, yaitu maaf, minta maaf, mohon maaf, maafkan, dan sori. Sedangkan tindak tutur ampun dibagi menjadi dua ragam tindak tutur, yaitu minta ampun dan mohon ampun. Masing-masing fungsi dan peranan dari tindak tutur meminta maaf yang menunjukkan kesantunan berbahasa akan diuraikan sebagai berikut.

1. Maaf

Maaf merupakan ungkapan verbal yang digunakan untuk menyampaikan penyesalan atau permintaan maaf atas kesalahan yang dilakukan. Tindak tutur maaf juga dapat digunakan untuk kepentingan lain (Nugroho, 2018: 722). Maaf merupakan sinonim dari sori. Akan tetapi keduanya memiliki perbedaan, yaitu perbedaan pada fungsi dan peranannya dalam percakapan bahasa Indonesia. Hal itu juga sangat berpengaruh terhadap tingkat kesantunan berbahasa seorang penutur. Secara umum penggunaan kata maaf digunakan dengan tujuan untuk kesantunan dalam bertutur. Sedangkan penggunaan kata sori digunakan ketika penutur berbicara dengan lawan tutur yang hubungannya sudah akrab, antara lain adik, kakak, saudara, teman, sahabat, dan sebagainya. Tindak tutur maaf dibagi menjadi lima ragam tindak tutur, yaitu maaf, minta maaf, mohon maaf, maafkan, dan sori.

Ragam minta maaf kedudukannya lebih tinggi di atas ragam maaf. Jika dilihat dari segi kesantunan berbahasa, ragam minta maaf juga lebih santun daripada ragam maaf. Berbeda lagi 
dengan ragam mohon maaf yang merupakan ungkapan verbal, umumnya digunakan untuk menyampaikan pertanyaan, pernyataan, atau kesalahan yang dilakukan penutur kepada orang yang lebih tua atau dihormati oleh penutur. Secara umum penggunaan ragam mohon maaf digunakan dengan tujuan untuk kesantunan dalam bertutur. Tingkatan ragam mohon maaf kedudukannya lebih tinggi di atas ragam maaf dan minta maaf. Jika dilihat dari segi kesantunan berbahasa, ragam mohon maaf juga lebih santun daripada ragam maaf dan minta maaf.

Bentuk tindak tutur maaf sendiri dapat ditemukan dalam beberapa situasi, di antaranya permintaan maaf atau sori, penguat keterangan (adverba penguat), ekspresi perasaan, ungkapan yang menandakan laras maaf, dua kata penguat atau ulangan adverba penguat, tolong, menyatakan kekhawatiran, menyalahkan diri sendiri, ketidak sengajaan, mengungkapkan rasa malu, pengakuan terhadap fakta tapi bukan tanggung jawab, tidak mau mengakui kesalahan, memberi penjelasan atau pertimbangan, menawarkan pembaikan atau pembetulan keadaan, dan berjanji tidak mengulangi kesalahan. Berikut analisis yang dapat memudahkan seorang penutur bahasa Indonesia dan pemelajar BIPA untuk memahami penggunaan fungsi dan peranan masing-masing ragam maaf dalam beberapa situasi tertentu.

a. Permintaan maaf atau sori

- Maaf: "Maaf, aku memang salah."

- Minta maaf: "Saya minta maaf."

- Mohon maaf: "Saya mohon maaf."

- Maafkan: "Maafkan saya ya."

- Sori: "Sori, aku salah."

b. Penguat keterangan (adverba penguat)

- Maaf: "Maaf, kemarin aku tidak bisa ikut main ke rumahmu karena sakit perut."

- Minta maaf: "Saya minta maaf atas seluruh kesalahan yang pernah saya perbuat."

- Mohon maaf: "Mohon maaf, pak dosen saya terlambat masuk kelas dikarenakan tadi ban sepeda motor saya kempis."

- Maafkan: "Maafkan aku yang kemarin tidak bisa hadir di acara pernikahanmu, karena sedang menemani ibuku di rumah sakit."

- Sori: "Sori bukumu belum aku kembalikan, karena aku belum selesai membacanya."

c. Ekspresi perasaan

- Maaf: "Maaf, jika aku melukaimu."

- Minta maaf: "Aku minta maaf, jika sering memarahimu."

- Mohon maaf: "Mohon maaf atas segala perkataan dan perbuatan saya yang menyinggung hati, Bapak."

- Maafkan: "Maafkan aku, karena gagal menjadi teman yang baik untukmu."

- Sori: "Sori, aku sedang ingin menyendiri."

d. Ungkapan yang menandakan laras maaf 
- Maaf: "Maaf, aku tidak bermaksud meninggalkanmu."

- Minta maaf: “Assalamu'alaaikum Bibi, saya minta maaf karena tas Bibi belum saya kembalikan."

- Mohon maaf: "Saya mohon maaf, apabila selama mendampingi murid-murid banyak melakukan kesalahan."

- Maafkan: "Maafkan aku, yang selalu membuatmu marah."

- Sori: "Sori, aku memang salah karena tidak mendengarkan perkataanmu."

e. Ulangan adverba penguat (penguat keterangan)

- Maaf: "Maaf, aku sangat-sangat tidak sengaja."

- Minta maaf: "Saya minta maaf banyak-banyak, karena saya memang bersalah."

- Mohon maaf: "Mohon maaf, saya sangat-sangat menyesal."

- Maafkan: "Maafkan kami, yang benar-benar ceroboh ini."

- Sori: "Sori, aku sangat-sangat gegabah."

f. Tolong

- Maaf: "Tolong beri aku maaf."

- Minta maaf: "Tolong, saya sedang minta maaf padamu."

- Mohon maaf: "Tolong, saya mohon maaf dengan sangat."

- Maafkan: "Tolong maafkan aku."

g. Menyatakan kekhawatiran

- Maaf: "Maaf, apakah kamu mengalami cedera?"

- Minta maaf: "Saya minta maaf, apakah ada yang sakit setelah jatuh tadi ?"

- Mohon maaf: "Mohon maaf, Ibu. Apakah Ibu sakit ?"

- Maafkan: "Maafkan aku telah menginjak kakimu, apakah sakit ?"

- Sori: "Sori, apa kamu baik-baik saja ?"

h. Ketidak sengajaan

- Maaf: "Maaf, aku tidak sengaja."

- Minta maaf: "Saya minta maaf, karena tidak melihat."

- Mohon maaf: "Mohon maaf, Ibu saya kurang tahu."

- Maafkan: "Maafkan, aku tidak sengaja."

- Sori: "Sori, aku tidak melihatnya."

i. Mengungkapkan rasa malu

- Maaf: "Maaf, saya salah orang."

- Minta maaf: "Saya minta maaf, karena ternyata bukan kamu yang saya cari."

- Mohon maaf: "Mohon maaf, salah sambung."

- Maafkan: "Maafkan, aku salah ngomong."

- Sori: "Sori, ternyata aku salah kostum."

j. Pengakuan terhadap fakta tapi bukan tanggung jawab 
- Maaf: "Maaf, aku tidak melihat papan tanda."

- Minta maaf: "Saya minta maaf, saya akan parkir di tempat lain."

- Mohon maaf: "Mohon maaf, saya tidak melihat simbol itu."

- Maafkan: "Maafkan, aku tidak tahu lambang ini."

- Sori: "Sori, aku tidak melihat papan pengumuman."

k. Tidak mau mengakui kesalahan

- Maaf: "Maaf, aku tidak melihat."

- Minta maaf: "Minta maaf, aku tidak mendengar."

- Mohon maaf: "Mohon maaf, Ibu. Saya tidak tahu."

- Maafkan: "Maafkan, aku tidak merasakannya."

- Sori: "Sori, aku tidak melihat."

1. Memberi penjelasan atau pertimbangan

- Maaf: "Maaf, buku ini terlalu tebal sehingga aku kesulitan memahaminya."

- Minta maaf: "Minta maaf, tadi sore aku lupa mengangkat jemuran dan akhirnya jemurannya basah kehujanan."

- Mohon maaf: "Mohon maaf, Bapak. Saya akan menulis sebuah artikel untuk diseminarkan di Universitas Pamulang."

- Maafkan: "Maafkan aku, letak SMA itu terlalu jauh dari rumahku sehingga aku tidak mungkin berangkat dengan bersepeda."

- Sori: "Sori, aku pakai masker untuk mematuhi protokol kesehatan."

m. Menawarkan pembaikan atau pembetulan keadaan

- Maaf: "Maaf, aku akan menggantikannya untukmu."

- Minta maaf: "Saya minta maaf, karena telah merusakkan bajumu. Saya janji akan menggantikannya dengan yang lain."

- Mohon maaf: "Mohon maaf, saya akan segera melunasi hutang-hutang saya, Pak."

- Maafkan: "Maafkan, aku akan melunasinya besok."

- Sori: "Sori, nanti aku saja yang belanja makanan."

n. Berjanji tidak mengulangi kesalahan.

- Maaf: "Maaf, aku berjanji tidak akan mengulanginya lagi."

- Minta maaf: "Saya minta maaf dan berjanji tidak akan mengulangi kesalahan yang sama."

- Mohon maaf: "Mohon maaf, Pak. Saya berjanji tidak akan terlambat masuk kuliah lagi."

- Maafkan: "Maafkan saya, saya berjanji akan mematikan gawai ketika di perpustakaan."

- Sori: "Sori, aku tidak akan menjauhimu lagi."

2. Ampun

Ampun merupakan sinonim dari maaf, tetapi ampun identik dengan adanya kesenjangan kelas yang sangat jauh antara penutur dan lawan tutur. Misalnya, seorang raja memberi ampun 
kepada rakyat yang telah melanggar peraturan atau janji. Jadi, sang raja memberikan ampunan kepada rakyatnya itu. Secara umum penggunaan kata ampun digunakan dengan tujuan untuk pembebasan dari tuntutan karena melakukan kesalahan atau kekeliruan. Jika dilihat dari segi kesantunan, kata ampun lebih tinggi tingkatannya daripada kata maaf, minta maaf, dan mohon maaf. Kata ampun dapat diklasifikasikan menjadi dua, yaitu minta ampun dan mohon ampun. Perbedaan antara keduanya terletak pada tingkatan dan fungsi penggunaannya. Tingkatan minta ampun lebih rendah daripada mohon ampun. Sedangkan fungsi penggunaan kata minta ampun, seperti seorang anak kepada kedua orang tuanya, atau murid kepada gurunya. Fungsi penggunaan kata mohon ampun memiliki tingkat yang tinggi. Penggunaannya biasa digunakan oleh seorang penutur bahasa kepada raja atau kepada Tuhannya. Supaya penutur bahasa Indonesia dan pemelajar BIPA dapat lebih paham dengan fungsi dan peranan tindak tutur ampun, maka perlu diberikan contoh penggunaan ragam minta ampun dan mohon ampun sebagai berikut.

a. Contoh penggunaan ragam minta ampun:

Ragam minta ampun seorang anak kepada ayahnya: "Saya minta ampun, Ayah karena sudah membuat Ayah terluka."

Ragam minta ampun seorang murid kepada gurunya: "Ibu guru, saya minta ampun atas kesalahan yang telah saya perbuat terhadap Ibu."

b. Contoh penggunaan ragam mohon ampun:

Ragam mohon ampun seorang hamba kepada Tuhannya: "Ya Allah, saya memohon ampun kepada$\mathrm{Mu}$ atas dosa dan kesalahan yang selama ini saya perbuat."

Ragam mohon ampun seorang rakyat kepada rajanya: "Saya mohon ampun kepada paduka Raja, dan saya memohon supaya saya tidak dijatuhi hukuman yang berat."

\section{SIMPULAN}

Terdapat dua bentuk tindak tutur meminta maaf, yaitu maaf dan ampun. Maaf merupakan sinonim dari ampun, tetapi ampun identik dengan adanya kesenjangan kelas yang sangat jauh antara penutur dan lawan tutur. Tindak tutur maaf diklasifikasikan menjadi lima ragam tindak tutur. Sedangkan tindak tutur ampun diklasifikasikan menjadi dua ragam tindak tutur. Masing-masing klasifikasi yang ada memiliki fungsi dan peranan yang berbeda serta penggunaannya sangat berpengaruh terhadap tingkat kesantunan berbahasa seorang penutur.

Penggunaan tindak tutur maaf berfungsi sebagai penyampaian perasaan menyesal atau permintaan maaf atas kesalahan yang dilakukan. Sedangkan penggunaan tindak tutur ampun berfungsi sebagai pembebasan dari tuntutan karena telah melakukan kesalahan atau kekeliruan. Untuk peran antara tindak 
tutur maaf dengan tindak tutur ampun juga sangat berbeda. Masing-masing memiliki peranannya sendiri yang diklasifikasikan menjadi beberapa macam ragam. Tiap ragam yang ada akan menunjukkan tingkat kesantunan berbahasa seorang penutur.

Bentuk tindak tutur maaf diklasifikasikan menjadi lima ragam tindak tutur, yaitu ragam tindak tutur maaf, minta maaf, mohon maaf, maafkan, dan sori. Masing-masing ragam tindak tutur tersebut dapat ditemukan dalam beberapa situasi, di antaranya permintaan maaf atau sori, penguat keterangan (adverba penguat), ekspresi perasaan, ungkapan yang menandakan laras maaf, dua kata penguat atau ulangan adverba penguat, tolong, menyatakan kekhawatiran, menyalahkan diri sendiri, ketidak sengajaan, mengungkapkan rasa malu, pengakuan terhadap fakta tapi bukan tanggung jawab, tidak mau mengakui kesalahan, memberi penjelasan atau pertimbangan, menawarkan pembaikan atau pembetulan keadaan, dan berjanji tidak mengulangi kesalahan.

Bentuk tindak tutur ampun diklasifikasikan menjadi dua ragam tindak tutur, yaitu ragam tindak tutur minta ampun dan mohon ampun. Perbedaan antara keduanya terletak pada tingkatan dan fungsi penggunaannya. Tingkatan minta ampun lebih rendah daripada mohon ampun. Fungsi penggunaan ragam minta ampun, dapat digunakan oleh seorang anak kepada kedua orang tuanya, atau murid kepada gurunya. Sedangkan fungsi penggunaan kata mohon ampun memiliki tingkat yang tinggi. Penggunaannya biasa digunakan oleh seorang penutur bahasa kepada raja atau kepada Tuhannya.

Dengan mempelajari dan memahami fungsi serta peranan dari masing-masing tindak tutur maaf dan ampun, penutur bahasa Indonesia dan pemelajar BIPA harus mampu mengimplementasikan tindak tutur maaf maupun ampun sesuai dengan tingkat situasi tutur dan kesantunan berbahasa. Sehingga pemelajar BIPA terutama tingkat A1 atau prapemula dapat berbicara dengan santun sesuai dengan kaidah bahasa Indonesia yang baik dan benar.

\section{DAFTAR PUSTAKA}

Fitriah, F., dan Fitriani, S.S. 2017. Analisis Tindak Tutur dalam Novel Marwah di Ujung Bara Karya RH Fitriadi. Jurnal Master Bahasa. 5 (1): 52.

Kartika, D. 2017. Strategi dan Penggunaan Modifikasi dalam Kesantunan Tindak Tutur Memohon Oleh Mahasiswa Jepang Pada Program Bahasa Indonesia Penutur Asing (BIPA). Indonesian Language Education and Literature. 2 (2): 137.

Nugroho. M. 2018. Penggunaan Kata Maaf Pada Pesan Whatsapp Studi Kasus Pesan Mahasiswa Kepada Dosen Sebuah Kajian Pragmatik. Pertemuan Ilmiah Bahasa dan Sastra Indonesia (PIBSI) 2018. 722.

Purba, A. 2011. Tindak Tutur dan Peristiwa Tutur. Jurnal Pendidikan Bahasa dan Sastra. 1 (1): 79.

Ridwan, M. 1996. Kajian Sosiopragmatik Tuturan Permohonan Maaf Oleh Penutur Bahasa Arab di Mesir. Prosiding Pragmatik: Sastra dan Linguistik. 126-127.

Sari, F.D.P. 2012. Tindak Tutur dan Fungsi Tuturan Ekspresif dalam Acara Galau Finite di Metro TV: Suatu Kajian Pragmatik. Jurnal Skriptorium. 1 (2): 2-3.

Yusof, M., Maros, M., dan Jaafar, M.F. 2011. Ooops.. Maaf: Strategi Kesopanan dan Penebus Kesalahan. Jurnal Melayu 8. 33-37. 